\title{
Pragmatism and the Social Sciences
}

A Century of Influences and Interactions, vol. 2

Roberto Frega and Filipe Carreira da Silva

\section{(2) OpenEdition}

Electronic version

URL: http://journals.openedition.org/ejpap/761

DOI: 10.4000/ejpap.761

ISSN: 2036-4091

Publisher

Associazione Pragma

Electronic reference

Roberto Frega and Filipe Carreira da Silva, «Pragmatism and the Social Sciences », European Journal of Pragmatism and American Philosophy [Online], IV - 1 | 2012, Online since 23 July 2012, connection on 24 September 2020. URL : http://journals.openedition.org/ejpap/761 ; DOI : https://doi.org/10.4000/ ejpap.761

This text was automatically generated on 24 September 2020

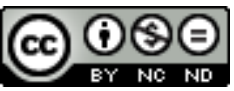

Author retains copyright and grants the European Journal of Pragmatism and American Philosophy right of first publication with the work simultaneously licensed under a Creative Commons AttributionNonCommercial-NoDerivatives 4.0 International License. 


\title{
Pragmatism and the Social Sciences
}

\author{
A Century of Influences and Interactions, vol. 2 \\ Roberto Frega and Filipe Carreira da Silva
}

1 This issue continues the symposia on Pragmatism and the Social Sciences: A Century of Influences and Interactions that has appeared in the vol. 2, year 2011 of this journal. For a general introduction to the issue we refer readers to our Editor's introduction to the volume 1.

2 This new issue, inspired by the same criteria used in the making of the first, is divided in three sections.

3 In the first section, titled "Classical Pragmatists and contemporary sociology" contains three papers, all dealing in different ways with the question of the legacy of pragmatism to contemporary social theory. All three papers tackle different strands of the appropriation of pragmatism in French social theory from Pierre Bourdieu to contemporary pragmatic sociology.

4 In the second section, titled "Law, Power, and the prospects of a pragmatist social theory," the selected article deal with more specific issues in social and political theory, always in ways that focus on the distinct contribution of the pragmatist tradition to contemporary research. The papers address issues that are of concern for social theory in broad sense, as well as for more specific fields such as international relation theory, the theory of power, the theory of historiography.

5 In the last section, titled "Contemporary appropriations," we have gathered articles that explore issues that extend beyond social theory to cover field such as the cognitive sciences, communication studies, and educational theory.

6 This volume closes the project. We hope that the articles published in both volumes will be of interest to philosophers as well as to scholars coming from other fields, and we hope in this way to have contributed to a broader understanding of pragmatism as a cultural enterprise that encompasses an increasing larger sphere of contemporary reflection. 


\section{AUTHORS}

ROBERTO FREGA

CNRS-IMM, Paris

fregarob[at]gmail.com

\section{FILIPE CARREIRA DA SILVA}

University of Lisbon

fcs23[at]cam.ac.uk 